\title{
Environmental management within the indigenous perspective
}

\section{Pengelolaan lingkungan dalam perspektif penduduk asli}

\author{
Andrian Dolfriandra Huruta $^{1}$ \& Maria Dyah Kurniasari ${ }^{2}$ \\ ${ }^{1}$ Faculty of Economics and Business, Universitas Kristen Satya Wacana \\ ${ }^{2}$ Faculty of Medicine and Health Science, Universitas Kristen Satya Wacana \\ Address: ${ }^{1} J a l a n$ Diponegoro No.52-60, Sidorejo, Salatiga, Central Java 50711 \\ ${ }^{2}$ Jalan Kartini No 11 A Salatiga, Central Java 50711 \\ E-mail: andrian.huruta@staff.uksw.edu \& maria.dyah@staff.uksw.edu
}

\begin{abstract}
The environment (nature) is one of the most important aspects of life that needs to be considered when referring to and regarding sustainable development. This article aims to describe environmental management based on local knowledge using the case study conducted focusing on Mbatakapidu. The environment, which is a space for people to create a sustainable livelihood, is increasingly being disturbed by the acts of humanity itself. However, we cannot deny that in addition to these conditions, there are still local communities that always strive to create a balance between human and the environment. One of them is a local community in Mbatakapidu. This study used a qualitative approach with a case study perspective. The data collection was done by conducting in-depth interviews with the informants. The six informants were determined purposively. The results of this study show that people of Mbatakapidu trust that there are spirits who inhabit the springs and forests. This is a form of local wisdom that makes them tend to hold on to destructive action against the forest. The people of Mbatakapidu make nature their friend, and seek not to exploit but desire to maintain the sustainability of nature with the traditional local knowledge that they have. It implies that the Mbatakapidu people are obedient to Marapu. The values embraced by Marapu makes people harmonise their life with the natural environment. Therefore, the act of field (savannah) burning turned out to be mobilised by the individual and not at the instigation of local values as believed by the Mbatakapidu.
\end{abstract}

Keywords: environment; development; local

\begin{abstract}
Abstrak
Lingkungan (alam) merupakan salah satu aspek penting yang perlu diperhatikan dalam pembangunan berkelanjutan. Tujuan penelitian ini adalah untuk menggambarkan pengelolaan lingkungan berbasis pengetahuan lokal dengan menggunakan studi kasus di Desa Mbatakapidu. Lingkungan yang merupakan ruang bagi manusia untuk menciptakan penghidupan berkelanjutan kini semakin terganggu eksistensinya oleh ulah manusia itu sendiri, namun tidak bisa kita pungkiri bahwa di samping kondisi tersebut, ternyata masih ada komunitas lokal yang selalu menjaga keseimbangan antara manusia dengan lingkungan, salah satunya adalah sebuah komunitas lokal di Desa Mbatakapidu. Penelitian ini menggunakan pendekatan kualitatif dengan studi kasus. Pengumpulan data dilakukan dengan melakukan wawancara mendalam dengan informan. Informan sejumlah enam orang ditentukan secara purposive. Hasil studi ini menunjukkan bahwa kepercayaan orang Mbatakapidu bahwa di lokasi mata air dan hutan terdapat roh yang mendiaminya merupakan suatu bentuk local wisdom yang membuat mereka segan dan sensitif untuk melakukan tindakan, yang sejatinya destruktif bagi eksistensi mata air dan hutan. Orang Mbatakapidu menjadikan alam sebagai sahabat, bukan untuk mengeksploitasinya secara tidak bertanggungjawab, tetapi menjaga keberlanjutan alam dengan pengetahuan lokal tradisional yang mereka miliki. Hal ini menunjukkan bahwa orang Mbatakapidu patuh terhadap Marapu. Nilai-nilai yang dianut dari Marapu membuat masyarakat menyelaraskan kehidupan mereka dengan lingkungan alam. Oleh karena itu, tindakan membakar padang (savana) yang selama ini terjadi ternyata dimobilisasi oleh oknum dan bukan atas anjuran nilai-nilai lokal yang selama ini diyakini oleh orang Mbatakapidu.
\end{abstract}

Kata kunci: lingkungan; pembangunan; local

\section{Introduction}

A development model planned by developing countries starts from the introduction of poverty problems, suburban communities, income inequality, unemployment (Sosrodihardjo 1987:6), the 
injustice of landlords, deforestation, health, human rights violations, war, divorce, adoption, land rights of indigenous peoples, access to technology, security and so on (Considine 2005). Why does it have to start in the village? This is being done while regarding that (1) the rural community is the majority of the population in the country and (2) the local community is still a structural determinant in relation to the national development that determines the success or failure of national development as a whole (Sosrodihardjo 1987:7).

Nowadays, there is an urge to pay heed to the importance of local wisdom as well as maturity when tackling intended development trajectories. In other words, the development should follow its logic course as a social change process based on certain values (Sosrodihardjo 1987:9). This is almost the same as the previous explanation, in that the intended value is a set of values that guides the behaviour of local communities.

In Indonesia, local wisdom plays an important role in balancing the state's domination in development activities toward its policy instruments. One resistance is by the Samin Community in the Kendeng Mountains (Pati, Central Java) through its local values banning the construction of a cement factory in the Karst Mountains. The main reason for this is that the factory will likely destroy the soil structure which will cause low water absorption, which ultimately reduces soil fertility. From the ecological side, there will be a negative addition to the investment activities possible. From that perspective, it assumes that the role of Samin under the social system and/or in relation to local values plays an important role in society.

The village of Mbatakapidu is one of the villages located in the "Sabana Sumba" region (Nugrohowardhani 2016). Since the authors' arrival in 2011, 2013, 2014 and 2018, the localised values that frame the development phenomenon there can clearly be seen. One of the development phenomena that has occurred in the village of Mbatakapidu was on 6th November 2013. One of the national private television stations, MNC TV (MNC group), reported that the village was ranked in the top ten for the local environment-based management category. The Mbatakapidu area is one of conservation areas in Waingapu sub-district (East Sumba-East Nusa Tenggara). This is because Mbatakapidu is the source of the springs used as a source of clean water for the people in the subdistricts of Waingapu and Kambera. The allocation of clean water is administered by the Water Supply Company (PDAM) of Matawai Amahu and also managed by one private company (PT Aguamor) which produces bottled drinking water. On the other hand, the existence of savannah grasslands in Mbatakapidu is the concern of all Mbatakapidu people and the government in the context of responding to the padang fires happening in Mbatakapidu.

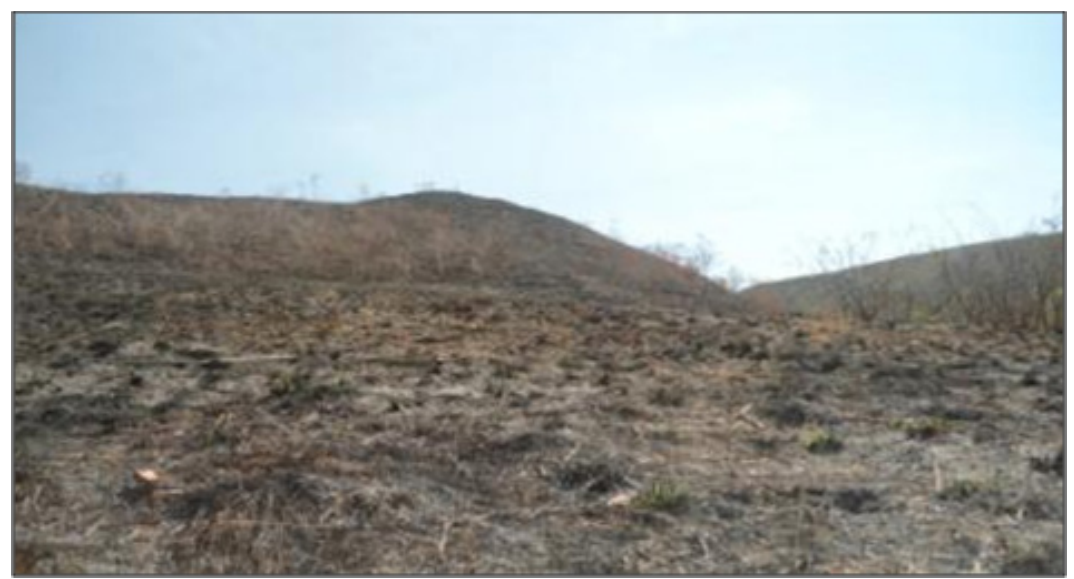

Figure 1.

Savannah Mbatakapidu condition during the dry season Source: Privat Documentation (2014)

From this existing condition, the problem shown is whether the savannah burning that has been happening in the village of Mbatakapidu is mobilised by one person or on the recommendation of the local values believed by the Mbatakapidu people? 
This study refers to previous studies such as those of Kana (1983), Vel (2010), Wellem (2004), Foni (2003), Palekahelu (2010), Sugianto (2011) and Anthonius (2016) regarding the tribes and communities in the provinces of East Nusa Tenggara in relation to implementing local values, especially those tied into environmental management. There are two important points that can be deduced from the previous studies; 1) the existence of efforts to maintain the local wisdom that has existed for generations and 2) the emerging awareness of local identity in the modernisation era. Therefore, this study is important in order to understand environmental management by the Mbatakapidu people in order to establish sustainable development.

\section{Research Method}

This study used a qualitative approach involving a case study (Wilardjo 1994) focused on Mbatakapidu village. The reason for selecting Mbatakapidu village was based on the consideration that: 1) administratively, Mbatakapidu village is one of the two villages (see Pambota Njara) located in Waingapu Sub-district (read: villages in the middle of town). This condition has triggered the paradox of growth and development in Mbatakapidu village. This growth and development paradox is shown in the structural transformation process, moving from focusing on the agrarian sector to focusing on industry. This is as well as the meeting of local values (rural society) and modern values (urban society) and 2) Mbatakapidu village area is also one of conservation areas of Waingapu Township (East Sumba Regency, East Nusa Tenggara Province). This is because Mbatakapidu is the source of the springs used as a source of clean water for the people in the sub-districts of Waingapu and Kambera.

Furthermore, in order to understand the depth of the researched phenomena, the author used data collection techniques through the medium of in-depth interviews with 6 informants from Mbatakapidu village. Methodically, the data sources used in this study included both primary and secondary data. To obtain the primary data in accordance with the case study research standards, the authors began with the collection of data by observing the study sites. Other data sources used as secondary data were the field reports from previous studies.

In order to maintain the correctness of the data collected in the interview, the writer must match the informant with another informant. Similarly, the observations in a select context were double checked by comparing them with other observations in an equal situation. This process is called crossexamination or triangulation (Wilardjo 1994), while the data collected from the field was analysed by using the descriptive analysis technique. Using the descriptive analytical technique, it illustrated all of the data and facts obtained by developing categories relevant to the purpose of the research. The interpretation of the results of the descriptive analysis referenced the relevant approach. The analysis of the data was carried out inductively, by first analysing and understanding the reality and then defining the theoretical framework or findings that are relevant to the topic studied. Furthermore, this study will discuss their reality in relation to the previous findings in order to produce a synthesis.

\section{Results and Discussion}

The belief in the Marapu (Ancestors) is binding for the Sumba people, so they have to stay in the existing region. The term "binded" (or binding) means that this belief conditions its followers to stay close to the centre of their life in Paraingu, where their Marapu resides. It is the Marapu who will lead them to Parai Marapu as their place of life after death. Therefore, many Sumbanese are reluctant to live far from their village of birth. In short, the Marapu's beliefs are tied down, but at the same time, they serve to strengthen the solidarity of the society. Although it does tie down and condition people to accept life in a dry and difficult terrain, it does not make the Sumbanese a passive community that accepts the difficulties of life. Marapu also functions to support the community by encouraging them to survive, to adapt to the dry and difficult natural environment, and to face food uncertainties and insecurity. This can occur because of the value of Marapu which is firmly held and embraced by the community. The three Marapu values include: 1) Marapu encourages people to maintain their 
identity as a source of mutual strength (solidarity), 2) Marapu conditions people to harmonise their lives with the natural environment and others as the main support of their lives and 3) Marapu forms a leadership pattern that is effective in managing communities that live in dry and difficult areas (Palekahelu 2010).

Furthermore, Marapu is a trigger factor to prompt harmonisation with the environment. Life in a dry region and with very limited natural resources requires three important things: a) nature must always be preserved, b) the efficient utilisation of natural resources and c) the fair use of natural resources. The principle of justice becomes very important in order to avoid the excessive exploitation of individuals and nature. In the context of the Sumbanese, the recognition of the existence of Alkhalik as the source of life and the owner of the whole of nature is the first foundation (Nuku) in the order of life (Lii Ndai) as agreed by the ancestors (Marapu). This understanding shapes people's awareness that nature is the source of life that must be preserved in order to sustain their lives. The efforts to preserve nature are held through rituals performed before and after exploiting the existing natural resources and also through the formation of myths attached to the natural resources. There is the myth that the spring will dry out when the trees around it are cut, for example, which is an effective reproach to safeguard people's actions against natural destruction. These rituals and myths function at the same time to build the awareness of the community to utilise the existing natural resources in a responsible manner that is both efficient and fair (Palekahelu 2010).

\section{The water house of life}

The spring located in Kullu village is a conservation area. This location drains water for the people in the districts of Waingapu and Kembera. In this location, there are many long-lived trees that stand upright and increasingly make the location shady. Since ancient times, this location was considered to be sacred by the community because the local community believed that in each location, the spring was guarded by the spirits of the ancestors (Marapu). This is what makes the Mbatakapidu people always keep the location of the springs safe from illegal logging activities.

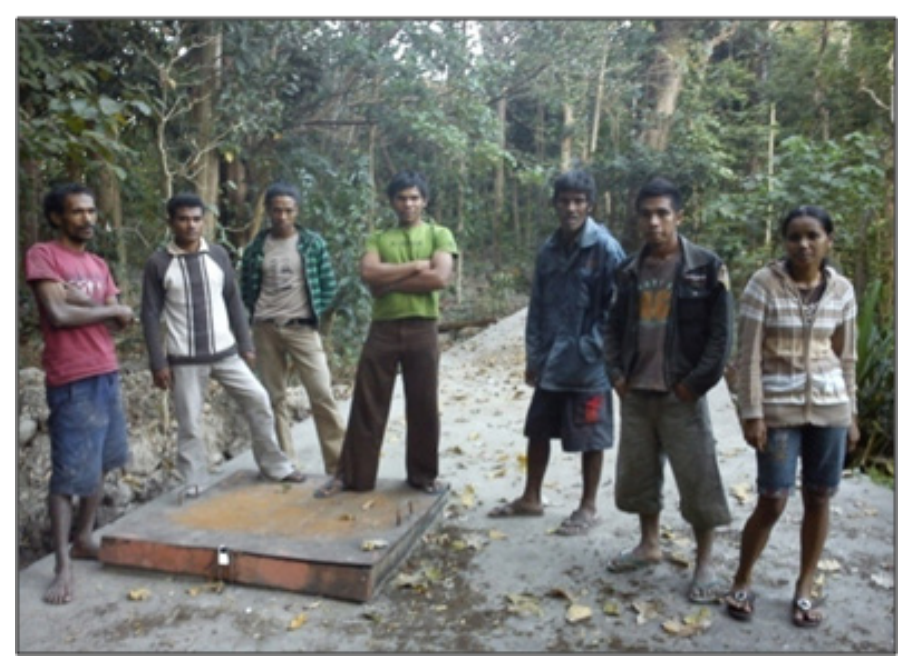

Figure 2.

The author with several residents at the location of water springs in Kampung Kullu Source: Personal Documentation (2011)

Regarding this case, the informant said that:

"The proximity between the Mbatakapidu people and nature, especially in the forests, is very high. It is consider taboo to cut trees and to take firewood from the location of the Kullu springs. These are the values inherited by our ancestors. If the trees around the spring are cut carelessly then it will cause the water flow of Kullu to decrease. This 
occurs because the trees that bind the ground water have been reduced. Of course, this will grant a negative externality to the fulfilment of clean water needs. The closeness of the Mbatakapidu people to nature does not necessarily make them more dependent on nature. Nevertheless, it makes them friendlier with nature" (Tanda 2014).

In line with the narrative by Tanda, then Landjamara also said that:

"I was a keeper of the Kullu spring from 1999 to 2014 (approximately 14 years). I was paid by the PDAM of Matawai Amahu, around Rp 1.250.000, -. Ever since I was little and until I was entrusted to be the guardian of the location of the spring, the Mbatakapidu people never dared to take firewood and cut down trees at the location of the spring. This is due to the values and norms believed by the people, which are focused on not carelessly interfering with the ecological balance at the location of the spring".

This is confirmed by Retangu, who said that:

"Due to the strong belief in the values and norms that make us, the Mbatakapidu people do not dare to cut down the trees and pick up firewood at the springs. This keeps the ecology around the springs balanced".

From the narrative of the informants, it was illustrated that the people's appreciation for the natural environment makes them friendlier to nature. This condition makes the location of the spring water in Kullu village safe from irresponsible people. This means that there is a communal awareness of the Mbatakapidu people guarding the creation of God.

In using the forest wood in the context of housing utilities, the Mbatakapidu do not use the wood from around the area of the spring. They use trees in another set location as according to custom and societal rules. Regarding this case, the informants said:

"If you want to cut wood, then you must do hamayangu to the marapu first. This has to be
done to ask permission of the forest dwellers. After that, the process of cutting the wood can
begin. The wood that is cut is also chosen or there is a certain wood suggested by the custom
leaders. After finished cutting the wood, then there should be a stone placed on the tree trunk.
This is because the people believe that after we cut the wood, it will have a new stump or
shoot that grows. This is one form of the appreciation of the Mbatakapidu people to nature"
(Tanda 2014).

In line with the narrative by Tanda, then Landjamara also said:

"When someone wants to cut wood in the forest, they must ask the owner first. Similarly, if someone wants to enter the house then they have to knock on the door. You have to do hamayangu to the marapu first. After being cut, there should be a stone placed in order to encourage new shoots to grow".

Nggandung also said that:

"If you take the wood in the forest then you have to do hamayangu to the marapu, it means that you have to ask the landlord first. If you cut the wood carelessly, you could get sick afterwards. Just above the slash it should be laid stone so that later it can grow new shoots. This is the local value that we must preserve to maintain environmental sustainability".

From the narratives of Tanda, Landjamara, Retangu and Nggandung, it was illustrated that there is adherence from the Mbakakidu people not to carelessly manage the natural resources in maintaining springs and using forest products. In line with Schumacher's view (1979) who stated that by upholding wisdom means it will trigger sustainability. The wisdom allows us not to pursue material interests and be more inclined to pursue spiritual goals. The moral and spiritual values are like traffic signs that can reduce greed which can destroy humans themselves. If humans continue to obey their greed and think that nature is created to be exploited then nature will continue to experience degradation and it is hard to do recovery. Human beings who feel they have mastered nature and caused damage mean unconsciously self-destructive because humans are part of nature. 


\title{
The water life keeper
}

The existence of springs cannot be separated from the presence of the guardian. The Mbatakapidu people believe that in the location of the springs dwells the spirit of their ancestors. The ancestor (Marapu) guards the spring from the destructive efforts carried out by irresponsible individuals. Sometimes the people who conduct this illegal activity suffer illness and ended up dead. Related to this case, an informant mentioned the following:

"In July 2014, there was a tub or a tank worker in the spring of Kullu who died suddenly. It is alleged that he did a deviant thing in the location of the spring. At the time, his condition was very weak, so he had to be taken to the local hospital. The superintendent drove him to the hospital by motorcycle. While on the way, precisely in the area of Pala Kanjilu, the person became unconscious. The supervisor panicked and dropped him off with his friend in the area and drove straight to the Nusantara shop to get a car. Arriving at the shop, the supervisor was not able to get a car, so the supervisor hurriedly went to the Brimob command headquarters in order to transport his colleague to Umbu Rara Meha Hospital. I myself was shocked because the day before he died, he and a friend came to ask for chili in the garden behind the house. They got one kabba (coconut shell made as a bowl) and after that, they immediately said goodbye to the camp at the location of the springs. Previously I have had advised the contractor to do the hamayangu to the marapu before working on a tub or a tank at the spring, but the contractor ignored this. I am very confident that this is what caused this tragic event to occur." (Landjamara 2014).

In line with the narrative of Landjamara, Landja also said that:

\begin{abstract}
"The location of the springs in Manu Rara village is a source of mystical experiences. This place is very sacred. This is what keeps this location safe from exploitative and irresponsible people. There used to be people from Sabadita Sabu who came to shoot the bats at the location of the springs. Strangely, this guy was determined to enter the springs, even after we warned him. While he was shooting, he met a father and son who were standing near to the springs. However, the two men did not speak a word. After finishing the shoot, the Sabu person immediately asked of and informed me of the characteristics of the two men and I said that the two men were the bodies buried a week ago in the hamlet of Manu Rara. The Sabu man was very shocked and frightened when he heard it. From that time on and until now, the Sabu people never come to this village, especially the spring, to hunt the bats".
\end{abstract}

From the narratives of Landjamara and Landja, it has been illustrated that there is a strong belief from the Mbakakapidu that there is a spirit that inhabits the location. This makes people reluctant to undertake any deviant actions in the area. This is in line with Hadiwijono's (2009:3) view that there is a belief in the existence of spirits that inhabit the whole universe. This has been confirmed by Keraf (2002), who described the local wisdom as all forms of knowledge, belief, understanding, insight, customs and ethics that guide human behaviour in life within the ecological community.

\section{Between the valued and deviant actions by an individual}

The savannah fire incident in Mbatakapidu is a common thing that occurs every year. This scene will be observed clearly during the dry season. Is this indeed a recommendation of the value adopted by the Mbatakapidu people? Or is this an irresponsible act? Related to this, the informant mentioned the following:

\footnotetext{
"As for us in Mbatakapidu village, there have never been local values that have suggested and guided the people to burn the savannah. If this is the result of an ancestral culture, then there must be a certain ritual to burn the field. But because of its proximity to the environment, it becomes the hallmark of ancestral values (marapu). Savannah fires are caused by irresponsible actors. For instance, there is a cattle herder who wants his cattle to get green grass in mapu (rumba mappu) during the dry season. He has to burn the fields and sometimes there are people who throw cigarette butts in the middle of
} 
the field without thinking. As a result of this action, the fire spreads to burn most of the fields and further spreads to the forest. It is different when people want to burn the slash, as they have to burn it at the beginning of the rainy season. This is so then the rain will extinguish the fire by itself and not allow it to spread to the fields or forests" (Tanda 2014).

From the narrative of the informant, it was illustrated that the burning of the savannah that has been happening in Mbatakapidu is purely due to an act by individual not advocated by the local values. Individual behavior tends to lead negative externalities, whereas cultural behaviour such as burning slashes according to the customary provisions will result in positive externalities.

As a result of the individual's actions, the soil has become damaged (lost fertility) and the livestock of Mbakakapidu have suffered injuries within the mouth which leads to death. This was confirmed by the informant who mentioned that:

"We don't carelessly burn the desert. We respect the local values to preserve nature. This is usually done by irresponsible people. As a result, the soil becomes damaged and when the horse eats the grass, it can swell up its mouth (mbbua nguara) because the horse consumes kanjirru mappu (mapu grass stems that still stand upright and sharp)" (Landja 2014).

From the narrative of Landja, it was illustrated that the people in Manu Rara village were very sensitive to the act of burning the fields, as it mad the land damaged and livestock injured. This happens because they are bound by their values and norms. Burning-related activities will only take place in October or November when the rains have fallen. This is done in order to maintain soil fertility. The burning of the savannah is done by individuals who apparently under the influence of social jealousy. This was confirmed by the informant who mentioned that:

"The individual who intends to burn the savannah does so due to social jealousy. It means that the burner burns the savannah in order to maintain their livestock's food. This is a deviant behaviour by the individual and is not the result of the values adopted by the Mbakakapidu people. People (individuals) deliberately burn the fields usually because they do not have livestock and are unable to steal cattle belonging to his fellow men. Shortcuts such as burning the fields are considered appropriate. We people, Mbatakapidu, hold fast to the advice of the ancestors who say namma mbaddi lima, tunnu padangu dangu namma uli eti djaka na laku la omangu na yappa ya kataru, why do you behave la luku na huaba ya wuya (who likes to steal, burn the field and snobby, whenever they go to the forest, they will be bitten by a snake and they go to the river, he will be swallowed by a crocodile)" (Retangu 2014).

From Retangu's illustration, it was illustrated that social jealousy drove the person to act outside of the stated values and norms. Meanwhile, the values and norms adopted by the Mbatakapidu people manage not to damage nature, especially related to cattle grazing.

The laziness factor could also be triggered, as the individuals a thing which was considered to be deviant regarding the local values and norms. For instance, firing and burning the field. This was confirmed by the informant who mentioned that:

"There were Mbatakapidu (the individual) who, when they were returning from the paranggangu (traditional market) in the village of Pambotandjara, carried too much luggage on their horses. Because the load was too heavy, in the middle of the trip, the person set down some of his belongings and because there was no other choice, he burned some of the items in the middle of the field. This caused the fields to burn and spread to the forest. This is considered an irresponsible act. The values and norms taught by the ancestors of Mbakakapidu are very contrary to the actions of individuals" (Enda 2014).

From the narrative of Enda, it was illustrated that the lazy attitude of a person is capable of causing a pasture or forest to be burnt. This happens because inside, the person's personality is no longer adhering to the societal values and norms, and they have no self control. 
From the collective narrative of the informants, it can be illustrated that the fires in the field/savannah that have been happening is purely due to an irresponsible act by individual and not a part of the values and norms believed by the Mbatakapidu people. This is in line with the view of Schumacher (1979), who said that greed, envy and other deviant behaviours drive people to have the tendency to ignore local wisdom.

\section{Conclusion}

The belief of the Mbatakapidu people is that there are spirits that inhabit certain locations. This is local wisdom which makes them reluctant and sensitive to take action, which is often destructive in relation to the existence of the springs and forests. The adherence of the Mbatakapidu to Marapu forms the consciousness of the Mbatakapidu villagers, stating that nature is the source of life that must be maintained. The obedience of the Mbatakapidu people towards Marapu causes harmonisation within human and environmental relations. This means that the Mbatakapidu people consider nature to be a friend and do not to exploit it irresponsibly. They seek to maintain the sustainability of nature along with their traditional local knowledge. The burning of the fields that had been happening was actually mobilised by the elements and not according to the advice of local values believed by the Mbatakapidu people. This needs to be amended for future generations.

\section{References}

Anthonius B (2016) Nurani Orang Buna Spiritual Capital dalam Pembangunan. Kupang: Gita Kasih. Considine M (2005) Making Public Policy: Institutions, Actors and Strategies. Cambridge: Polity Press.

Enda HK (2014) [Personal communication] 21 September.

Foni W (2003) Budaya Bertani Atoni Pah Meto: Siklus Bertani Lahan Kering Atoni Pah Meto Tunbaba Timor, Nusa Tenggara Timur. Salatiga: Satya Wacana University Press.

Hadiwijono H (2009) Religi Suku Murba di Indonesia. Jakarta: BPK Gunung Mulia.

Kana NL (1983) Dunia Orang Sawu. Jakarta: Sinar Harapan.

Keraf S (2002) Etika Lingkungan. Jakarta: Gramedia.

Landja MH (2014) [Personal communication] 17 September.

Landja MH (2014) [Personal communication] 11 September.

Landjamara K (2014) [Personal communication] 10 September.

Nggandung UN (2014) [Personal communication] 12 September.

Nugrohowardhani RLKR (2016) Sabana Sumba: Kelembagaan dan Pembangunan Ekonomi Desa. Salatiga: Program Pascasarjana Universitas Kristen Satya Wacana.

Palekahelu DT (2010) Marapu Kekuatan di Balik Kekeringan: Potret Masyarakat Wunga Kabupaten Sumba Timur Provinsi Nusa Tenggara Timur. Salatiga: Satya Wacana University Press.

Retangu AVU (2014) [Personal communication] 08 Oktober.

Schumacher EF (1979) Kecil Itu Indah, Terjemahan. Jakarta: LP3ES.

Sosrodihardjo S (1987) Aspek Sosial Budaya dalam Pembangunan Pedesaan. Yogyakarta: Tiara Wacana Yogya.

Sugianto HAT (2011) Modal Spiritual Kekuatan Tersembunyi di balik Kemampuan Membangun: Potret Kekerabatan Warga Kampung Mondo Kecaamatan Borong, Manggarai Timur, NTT. Cianjur: Pertapaan Shanti Bhuana.

Tanda Y (2014) [Personal communication] 09 September.

Vel J (2010) Ekonomi Uma: Penerapan adat dalam Dinamika Ekonomi Berbasis Kekerabatan. Jakarta: KITVL Press.

Wellem FD (2004) Injil dan Marapu: Suatu Studi Historis Teologis Tentang Perjumpaan Injil dengan Masyarakat Sumba Pada Periode 1876-1990. Jakarta: BPK Mulia.

Wilardjo L (1994) Studi Kasus: Sebuah Panduan Praktis. Jakarta: Satya Wacana University Press dan Gramedia Widiasarana Indonesia. 